\title{
RADIONUCLIDES IN ANCIENT RELICS OBTAINED FROM THE MATSUSAKI SITE AND THE HIROHATA SHELLMOUND ON THE PACIFIC COAST OF JAPAN
}

\author{
Tomoko Ohta ${ }^{1,2} \cdot$ Yasunori Mahara $^{1} \cdot$ Takumi Kubota $^{1} \cdot$ Yu Saito $^{3} \cdot$ Satoshi Fukutani $^{1} \bullet$ \\ Toshiyuki Fujii ${ }^{1}$ Atsushi Ando ${ }^{4}$ Eiji Nakata ${ }^{5}$ Takanori Nakano ${ }^{3}$ Yoshiro Abe ${ }^{6}$ • \\ Akira Tatematsu ${ }^{7}$
}

\begin{abstract}
We compared 2 archaeological relics of different preservation environments, white substances adhering to a vessel from the Matsusaki site and to earthenware from Hirohata, by measuring their environmental radioactivity, ${ }^{14} \mathrm{C},{ }^{228} \mathrm{Ra} /$ ${ }^{226} \mathrm{Ra},{ }^{234} \mathrm{U} / 238 \mathrm{U}$, and ${ }^{87} \mathrm{Sr} /{ }^{86} \mathrm{Sr}$, and major element contents (Ca, Sr, Mg, Fe, and $\mathrm{Mn}$ ). The results showed that the 2 materials were somewhat different and also reflected differences in their preservation environments. The chemical elements that were more abundant in the Matsusaki sample than in the Hirohata sample, Fe, Mn, ${ }^{238} \mathrm{U}$, and ${ }^{232} \mathrm{Th}$ (parent of ${ }^{228} \mathrm{Ra}$ ), are also abundant in seaweed or seagrass. Contamination by ${ }^{14} \mathrm{C}$ derived from rainwater after atmospheric nuclear tests was clearly observed in the white substance from Hirohata.
\end{abstract}

\section{INTRODUCTION}

Radiocarbon (half-life $5730 \mathrm{yr}$ ) is naturally produced in the atmosphere by the cosmic-ray reaction ${ }^{14} \mathrm{~N}(\mathrm{n}, \mathrm{p}){ }^{14} \mathrm{C}$ (Libby 1946). As a consequence of nuclear weapons testing, the activity of ${ }^{14} \mathrm{C}$ in the atmosphere increased during the 1950s to 1960s; since the adoption of the Comprehensive Nuclear Test Ban Treaty, the level has decreased gradually. Furthermore, ${ }^{14} \mathrm{C}$ is artificially produced in nuclear power and reprocessing plants and then released into the environment (Uchrin et al. 1992). As modern rainwater contains higher ${ }^{14} \mathrm{C}$ than prior to nuclear tests, if a sample has been in an underground (or soil) environment and been in contact with infiltrated rainwater for many years, it may be contaminated by modern rainwater and thus show a younger than original age.

Many earthenware relics excavated at ancient Japanese sites were used for making salt. Because the earthenware is thin and easily cracked, it was frequently thrown away when no longer useful. At some salt-production sites, a white substance has been found adhering to the discarded salt-manufacturing earthenware.

The Matsusaki site in Aichi Prefecture and the Hirohata shellmound in Ibaraki Prefecture, Japan, are salt-production sites on the Pacific coast. The Hirohata shellmound dates to the Late Jomon to Final Jomon periods, whereas the Matsusaki site dates to the Kofun and Heian periods. Thus, the Matsusaki site and the Hirohata shellmound differ in age by several thousand years. A white substance was discovered adhering both to salt-manufacturing earthenware at Hirohata and to wooden tubing vessels and salt-manufacturing earthenware at Matsusaki. The wooden tubing vessels from Matsusaki are assumed to be ring pours, as these tubs were used to concentrate brine water. At Hirohata, a white substance adheres thinly to pieces of salt-manufacturing earthenware.

The preservation process of the white substances differs between the 2 sites. At Matsusaki, tubs on which a thick layer of the white substance had accumulated were buried by coastal sands. At the

\footnotetext{
${ }^{1}$ Research Reactor Institute, Kyoto University, Kumatori-cho, Sennan-gun, Osaka 590-0494, Japan.

${ }^{2}$ Corresponding author. Email: nakano-o@HL.rri.kyoto-u.ac.jp.

${ }^{3}$ Research Institute for Humanity and Nature, Honzan, Kamigamo, Kita-ku, Kyoto-shi, Kyoto 603-8047, Japan.

${ }^{4}$ College of Natural Sciences, Pusan National University, San30 Jangjeon-dong, Geumjeong-gu Busan 609-735, Korea.

${ }^{5}$ Central Research Institute of Electric Power Industry, Abiko-shi, Chiba 270-1194, Japan.

${ }^{6}$ School of arts and letters, Meiji University, Surugadai, Chiyoda-ku, Tokyo 101-8301, Japan.

${ }^{7}$ Heishu Hosoi Memorial Hall and Tokai City Local History Museum, Arao-cho, Tokai-shi, Aichi 476-0003, Japan.
}

C 2010 by the Arizona Board of Regents on behalf of the University of Arizona Proceedings of the 20th International Radiocarbon Conference, edited by A J T Jull RADIOCARBON, Vol 52, Nr 2-3, 2010, p 526-533 
Hirohata shellmound, shells and some earthenware fragments coated by the white substance were left in the ground for a long time after the site had been excavated by archaeologists. As a result, they were exposed directly to rainwater contaminated by modern ${ }^{14} \mathrm{C}$ derived from atmospheric nuclear testing. In contrast, it can be presumed that ${ }^{14} \mathrm{C}$ ages obtained from relics of the Matsusaki site was not strongly contaminated by modern rainwater, because the white substance is thick and buried deep.

In this study, we measured the environmental radioactivity of ${ }^{14} \mathrm{C}$ in the substances adhering to earthenware from the Hirohata shellmound to determine the ${ }^{14} \mathrm{C}$ age and to investigate the effect of contamination by modern rainwater on a sample's ${ }^{14} \mathrm{C}$ age.

\section{METHODS}

\section{Major Elements and Chemical Form of the Adhering Substances}

About $0.5 \mathrm{~g}$ of adhering material from each site was dissolved by $1 \mathrm{~N} \mathrm{HNO}_{3}$ and sample solutions were obtained. The sample solutions were filtered with a cellulose acetate membrane filter with a pore size of $0.45 \mu \mathrm{m}$, and the filtrate was diluted with ultrapure water. Concentrations of the major elements $\mathrm{Ca}, \mathrm{Mg}, \mathrm{Sr}, \mathrm{B}, \mathrm{Fe}$, and $\mathrm{Mn}$ in the samples were determined by inductively coupled plasma atomic emission spectroscopy (ICP-AES) using a ICPS7500 (Shimadzu Co., Ltd, Kyoto, Japan). The chemical composition of the samples was measured by X-ray diffraction (XRD) using a Rinto 2100 (Rigaku Co. Ltd., Osaka, Japan).

\section{Determination of ${ }^{234} \mathrm{U} /{ }^{238} \mathrm{U},{ }^{235} \mathrm{U} /{ }^{238} \mathrm{U}$, and ${ }^{228} \mathrm{Ra} /{ }^{226} \mathrm{Ra}$ Isotope Ratios}

A sample of the adhering substance was dissolved in $2 \mathrm{M} \mathrm{HNO}_{3}$, and the solution was filtered with filter paper (5A). The solution, which contained uranium and thorium, was loaded on a U-TEVA resin column (Sowa Trading Co. Inc., Tokyo, Japan), and the resin was rinsed with $2 \mathrm{M} \mathrm{HNO}_{3}$ after the thorium in the resin was removed. The ${ }^{238} \mathrm{U}$ in the sample solution was measured via inductively coupled plasma mass spectroscopy (ICP-MS) (Yokogawa Co., Ltd., Kyoto, Japan). Uranium isotopes $\left({ }^{234} \mathrm{U},{ }^{235} \mathrm{U}\right.$, and $\left.{ }^{238} \mathrm{U}\right)$ in the sample solution were measured by a thermal ionization mass spectrometer (TIMS), and the ${ }^{234} \mathrm{U} /{ }^{238} \mathrm{U}$ and ${ }^{235} \mathrm{U} /{ }^{238} \mathrm{U}$ ratios were calculated.

Radium isotopes ( ${ }^{228} \mathrm{Ra}$ and ${ }^{226} \mathrm{Ra}$ ) of samples of $\sim 10 \mathrm{~g}$ of adhering material were determined by $\gamma$ ray spectrometry (Seiko Co. Ltd., Osaka, Japan) by first packing them into an airtight tin canister for 1 month. This allowed ${ }^{214} \mathrm{~Pb}$ and ${ }^{228} \mathrm{Ac}$ to reach radioactive equilibrium with their parents, ${ }^{226} \mathrm{Ra}$ and ${ }^{228} \mathrm{Ra}$, respectively. The radioactivity of ${ }^{214} \mathrm{~Pb}$ and ${ }^{228} \mathrm{Ac}$ were determined by $351-$ and $911-\mathrm{keV} \gamma$ rays, respectively, using a Ge detector with $40 \%$ relative efficiency.

\section{Separation of Sr Isotopes and Determination of the ${ }^{87} \mathrm{Sr} /{ }^{86} \mathrm{Sr}$ Ratio}

About $0.5 \mathrm{~g}$ of each sample were soaked in ultrapure water for 3 days, and the water was then stored. The remaining sample was soaked in a solution of $1 \mathrm{M} \mathrm{CH}_{3} \mathrm{COONa}$ for 3 days, after which this solution also was stored. The remaining sample was submerged for 7 days in a solution of $1 \mathrm{M}$ $\mathrm{CH}_{3} \mathrm{COOH}$ containing sufficient $\mathrm{CH}_{3} \mathrm{COONa}$ to obtain $\mathrm{pH} 5$ in order to dissolve the carbonate. The remaining sample (only the Hirohata sample) was then soaked in $\mathrm{HCl}$. The residue was then dissolved in $\mathrm{HNO}_{3}-\mathrm{HF}-\mathrm{HClO}_{4}$. In all cases, a cellulose acetate membrane filter of $0.45-\mu \mathrm{m}$ pore size was used. A cation-exchange resin, $50 \mathrm{~W} \times 8,200-400$ mesh, $\mathrm{H}$ form (Muromachi Chem. Co., Ltd., Fukuoka, Japan) was used to extract Sr isotopes from all solutions. Isotopic measurements were performed using a Thermo Finnigan ${ }^{\mathrm{TM}}$ TRITON multi-collector thermal ionization mass spectrometer (TIMS). We used the results to calculate the ${ }^{87} \mathrm{Sr} /{ }^{86} \mathrm{Sr}$ ratios. 
The ratio of ${ }^{87} \mathrm{Sr} /{ }^{86} \mathrm{Sr}$ in a shell reflects that of seawater at the time the shell was collected from the sea. The ratio was determined in a fossil bivalve shell excavated from a pure shell layer (composed only of shells) at the Matsusaki site, because pure shell layers are less likely to have been contaminated. The shellfish that produced the fossil shell lived in the 8th century. The shell was washed with ultrapure water and then sampled with a dental drill, avoiding the surface. A 1-mg piece of the sampled shell was then extracted in $0.1 \mathrm{M}$ acetic acid/Na-acetate buffer. The extract was passed through the cation-exchange resin to separate and purify the $\mathrm{Sr}$ isotopes, which were then quantified via TIMS. The ${ }^{87} \mathrm{Sr} /{ }^{86} \mathrm{Sr}$ ratios were calculated as described above.

An earthenware sample from Hirohata was washed with ultrapure water and sampled by drilling. The sample was then dissolved in $\mathrm{HNO}_{3}$ - $\mathrm{HF}-\mathrm{HClO}_{4}$ and the $\mathrm{Sr}$ isotopes dissolved in the solution were separated as described above.

\section{Determination of Radiocarbon Activity}

The adhering materials were cut with a graver, avoiding the surface, and sampling only the inside part. About $0.5 \mathrm{~g}$ of sample was leached with $1.2 \mathrm{M} \mathrm{HCl}$ to remove contaminants, then the sample was rinsed with pure water. Samples were placed in phosphoric acid and $\mathrm{CO}_{2}$ gas was generated. The $\mathrm{CO}_{2}$ was reduced to graphite by heating to $600{ }^{\circ} \mathrm{C}$ with $\mathrm{H}_{2}$ and $\mathrm{Fe}$ powder. The ${ }^{14} \mathrm{C}$ activity was measured by accelerator mass spectrometry (AMS) (Compact-AMS, Paleo Labo, Gunnma, Japan).

\section{RESULTS}

\section{Chemical Composition}

Figure 1 shows the X-ray diffraction pattern of the adhesion substance. The mineral composition of the adhering material samples from both locations was calcite $\left(\mathrm{CaCO}_{3}\right)$. Concentrations of some elements along with a sample of sea algae obtained from the reference value of Yamamoto (1995) are shown in Figure 2. The concentrations of $\mathrm{Ca}$ and $\mathrm{Sr}$ in the samples were almost the same in both the Matsusaki and Hirohata samples, whereas the Fe and Mn concentrations in the Matsusaki sample were much higher than those in the Hirohata sample.

\section{U-series and Th-series $\left({ }^{234} \mathrm{U} /{ }^{238} \mathrm{U},{ }^{235} \mathrm{U} /{ }^{238} \mathrm{U},{ }^{228} \mathrm{Ra} /{ }^{226} \mathrm{Ra}\right.$ Isotope Ratios)}

The concentration of ${ }^{238} \mathrm{U}$ in the Matsusaki sample of adhering material was $7.3-7.5 \mathrm{mg} / \mathrm{kg}$. The ${ }^{235} \mathrm{U} /{ }^{238} \mathrm{U}$ and ${ }^{234} \mathrm{U} /{ }^{238} \mathrm{U}$ activity ratios in the adhering material were $0.04601(2 \sigma=0.00006)$ and $1.19(2 \sigma=0.07)$, respectively. The ${ }^{234} \mathrm{U} /{ }^{238} \mathrm{U}$ activity ratio in the adhering material was within the range found in natural environmental samples. The ${ }^{228} \mathrm{Ra} /{ }^{226} \mathrm{Ra}$ activity ratio in the Matsusaki sample was $0.59 \pm 0.11(1 \sigma)$.

\section{${ }^{87} \mathrm{Sr} /{ }^{86} \mathrm{Sr}$ Ratio of the Adhering Materials}

Figure 3 shows the relationship between the reciprocal of $\mathrm{Sr}$ concentration, $1 / \mathrm{Sr}$, and the ${ }^{87} \mathrm{Sr} /{ }^{86} \mathrm{Sr}$ ratio in various extracts from the adhering material samples. The seawater value shown in Figure $3 \mathrm{a}$ is the ${ }^{87} \mathrm{Sr} /{ }^{86} \mathrm{Sr}$ ratio of this fossil shell. The ${ }^{87} \mathrm{Sr} /{ }^{86} \mathrm{Sr}$ isotope ratio of the adhering material of the Matsusaki extracts ranged from 0.70920 to 0.70928 . Ratios of the residue of the adhering substance after the substance was extracted by acetic acid/acetate buffer and the shell of the Matsusaki were $0.70935 \pm 0.0008$ and $0.70918 \pm 0.00008$, respectively (Figure 3a). More specifically, the ratios of the various extracts obtained from Hirohata had the following values: $0.708870 \pm 0.000003$ for pure water, $0.708981 \pm 0.000003$ for acetate, $0.709043 \pm 0.000003$ acetic acid/acetate buffer, and $0.709145 \pm 0.000004$ for $\mathrm{HCl}$ solvent. The ratio of the Hirohata adhering substance and the earthenware were $0.709090 \pm 0.000004$ and $0.70842 \pm 0.000003$, respectively (Figure 3b). 

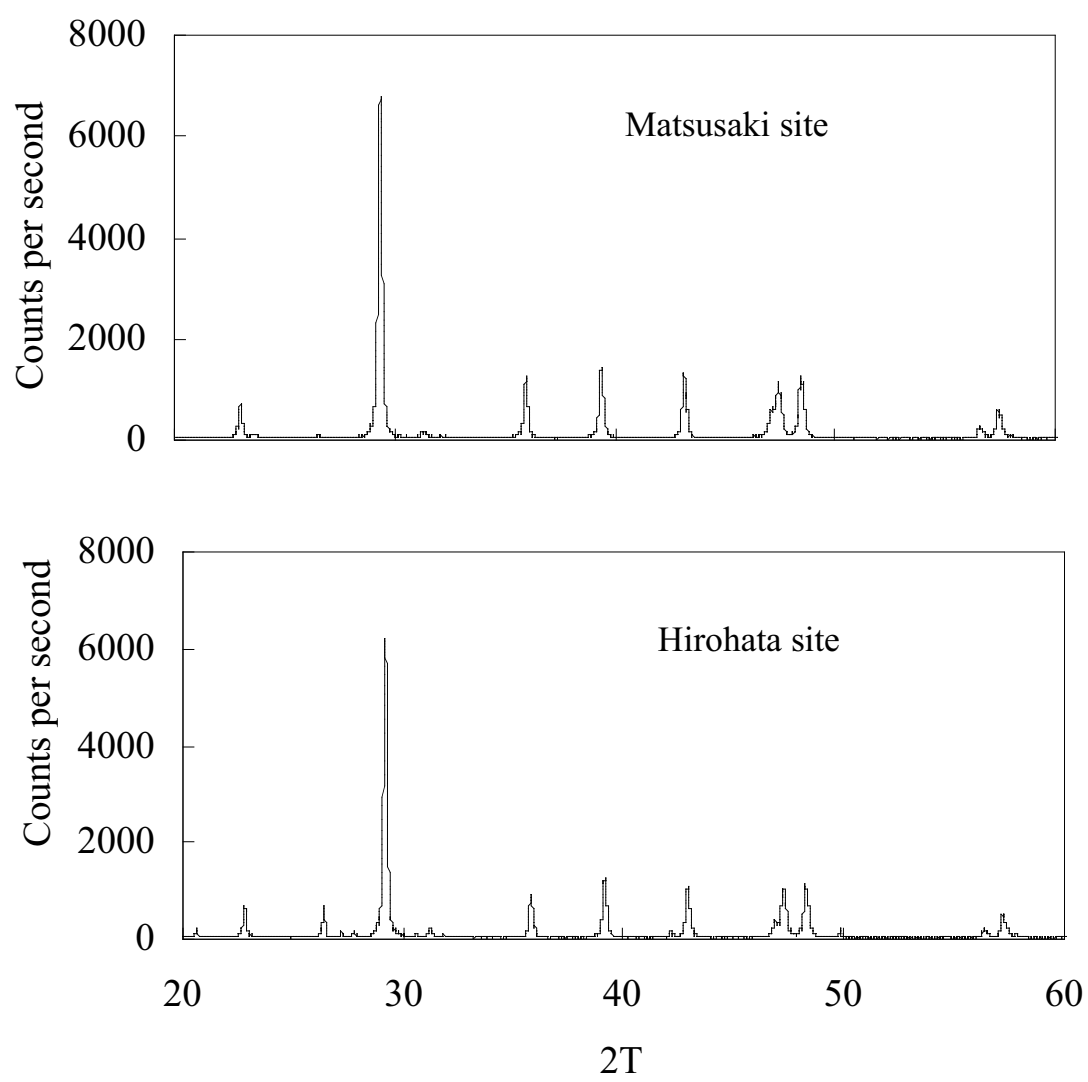

Figure 1 X-ray diffraction pattern of the adhering material from Matsusaki (a) and Hirohata (b)
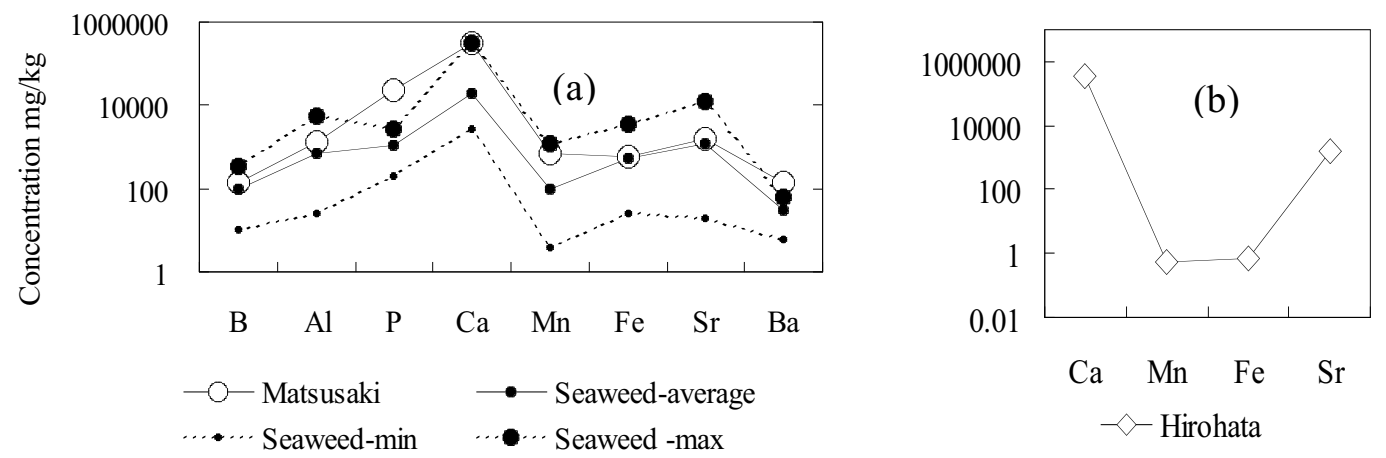

Figure 2 Concentrations of various elements in the Matsusaki (a) and Hirohata (b) samples compared to concentrations in seaweed for reference (a).

\section{Radiocarbon}

${ }^{14} \mathrm{C}$ in the white adhering substances was measured to investigate the possible influence of modern rainwater on the apparent age of the sample. Table 1 shows ${ }^{14} \mathrm{C}$ age of the samples, $\Delta \mathrm{R}$, and age calibrated by Marine 04 (Hughen et al. 2004). The values of $\Delta \mathrm{R}$ for the Matsusaki used $\Delta \mathrm{R}=-255$ and -146 (Nakamura et al. 2007). The $\Delta \mathrm{R}$ value used for Hirohata was $\Delta \mathrm{R}=133$, which is average value 

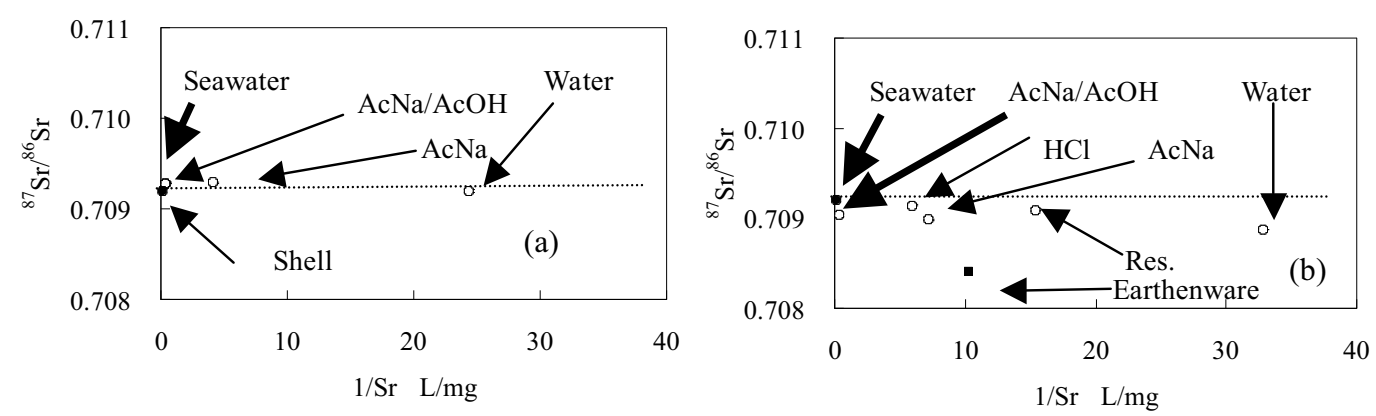

Figure $3{ }^{87} \mathrm{Sr} /{ }^{86} \mathrm{Sr}$ ratio in each of the extracted solutions from the adhering materials and shell from the Matsusaki site. Empty circles: adhering material extract; filled circles: seawater (fossil shell). (a) Matsusaki; (b) Hirohata. Res. = residue after carbonate of the sample was dissolved.

of Kanto district (Shishikura et al. 2007). The ${ }^{14} \mathrm{C}$ age of the Matsusaki and the Hirohata samples was $970 \pm 20 \mathrm{BP}(1 \sigma)$ and $1815 \pm 20 \mathrm{BP}(1 \sigma)$, respectively. ${ }^{14} \mathrm{C}$ ages calibrated using Marine04 (Hughen et al. 2004) for Matsusaki $(\Delta \mathrm{R}=-46$ and -255$)$ and Hirohata $(\Delta \mathrm{R}=133)$ samples were $A D$ $1070-1385(2 \sigma)$ and AD 647-785 $(2 \sigma)$, respectively. It is well known that the ${ }^{14} \mathrm{C}$ age of a marine sample is older than its original age, but if the ${ }^{14} \mathrm{C}$ derives not only from marine $\mathrm{C}$ but also from terrestrial or atmospheric $\mathrm{C}$, then the calibrated ${ }^{14} \mathrm{C}$ age by Marine 04 may be younger than the actual age. If the ${ }^{14} \mathrm{C}$ in the white adhering substance at the time of its formation originated from both marine $\mathrm{C}$ and terrestrial or atmospheric $\mathrm{C}$, the ${ }^{14} \mathrm{C}$ age of the Matsusaki sample might correspond roughly to its actual age. Even if mixing with terrestrial carbon is considered, the ${ }^{14} \mathrm{C}$ age of the Hirohata sample is much younger than its actual deposition age, which was during the Late to Final Jomon periods (3000-4000 yr ago).

Table $1{ }^{14} \mathrm{C}, \Delta \mathrm{R}$, and sample ages calibrated using Marine 04 data (Hughen et al. 2004).

\begin{tabular}{|c|c|c|c|c|c|}
\hline Site & Prefecture & $\begin{array}{l}{ }^{14} \mathrm{C} \text { yr BP } \\
(1 \sigma)\end{array}$ & $\Delta \mathrm{R}$ & $\Delta \mathrm{R}$ reference & Calibrated age range \\
\hline Hirohata & Ibaragi & $1815 \pm 20$ & 133 & Shishikura et al. 2007 & AD 647 (95.5\%) 785 \\
\hline Matsusaki & Aichi & $970 \pm 20$ & $\begin{array}{l}-255 \\
-146 \\
\end{array}$ & Nakamura et al. 2007 & $\begin{array}{l}\text { AD } 1070(95.5 \%) 1275 \\
\text { AD } 1183(95.5 \%) 1385\end{array}$ \\
\hline
\end{tabular}

\section{DISCUSSION}

\section{The Preservation Environments}

The preservation histories of the samples from Matsusaki and Hirohata are different. Since the Hirohata sample was exposed directly to rain, it was contaminated by modern ${ }^{14} \mathrm{C}$ derived from atmospheric nuclear testing. Therefore, the measured ${ }^{14} \mathrm{C}$ age is much younger than the actual deposition age. The ${ }^{14} \mathrm{C}$ age of the Matsusaki sample was only slightly younger than its original age. A high level of contamination with modern ${ }^{14} \mathrm{C}$ was detected in the white substance from Hirohata, which originated from rainwater that fell after atmospheric nuclear testing.

The ${ }^{87} \mathrm{Sr} /{ }^{86} \mathrm{Sr}$ ratio of the Hirohata sample dissolved in ultrapure water was slightly lower than that of contemporary seawater. This ratio was the lowest detected in any of the solutions, but the ratio in the earthenware sample was even lower (Figure $3 b$ ). The $\mathrm{Sr}$ isotope ratios of all Matsusaki sample extracts were about the same, suggesting that the $\mathrm{Sr}$ in all extracts had the same origin. For ${ }^{14} \mathrm{C},{ }^{87} \mathrm{Sr}$, and ${ }^{86} \mathrm{Sr}$, we attribute the source of the contamination of the Hirohata samples' original white substance to be mainly rainwater and/or the earthenware. 


\section{Differences in the Adhering Materials}

The ratios of the concentrations of $\mathrm{Ca}, \mathrm{Mg}, \mathrm{Sr}, \mathrm{Fe}$, and $\mathrm{Mn}$ in the adhering material from Matsusaki to their concentrations in the material from Hirohata were $1,0.4,0.9,10^{-6}$, and $10^{-5}$, respectively. The Fe and $\mathrm{Mn}$ concentrations in the Hirohata sample (Figure 2b) were much lower than those in the Matsusaki sample. Furthermore, the concentrations in the Matsusaki samples were similar to those in seaweed samples. Although mineralogically the samples from the 2 sites were basically the same in that both were calcite, they differed with respect to minor element composition.

The ${ }^{87} \mathrm{Sr} /{ }^{86} \mathrm{Sr}$ isotope ratio of modern seawater is $0.709175 \pm 0.000001$ (A Ando, personal communication 2008). The ${ }^{87} \mathrm{Sr} /{ }^{86} \mathrm{Sr}$ isotope ratio in the adhering substance sample from the Matsusaki site was similar to that of contemporary seawater, determined from the shell ratio. Thus, the adhering substance was mainly a marine product (of either seawater or something living in the sea). The production mechanism of the white substance has not yet been clear. Future work is required for examining the mechanism.

Miyake et al. (1970a) reported that the ${ }^{234} \mathrm{U} /{ }^{238} \mathrm{U}$ activity ratio in plankton and algae ranges from 1.07 to 1.18 , similar to that in seawater. The ${ }^{235} \mathrm{U} / 238 \mathrm{U}$ and ${ }^{234} \mathrm{U} / 238 \mathrm{U}$ activity ratios in modern seawater are 0.045-0.046 and 1.14-1.15, respectively (Somayajulu and Goldberg 1966; Joshi and Zingde 1998). The ${ }^{234} \mathrm{U} /{ }^{238} \mathrm{U}$ ratio in the Matsusaki sample was the same as that in seawater or a marine product. Concentrations of ${ }^{228} \mathrm{Ra}$ and ${ }^{226} \mathrm{Ra}$ in the surface seawater along the Pacific Ocean coast of Japan are $0.2-1.4$ and $1.1-1.9 \mathrm{mBq} / \mathrm{L}$, respectively, and the ${ }^{228} \mathrm{Ra} / 226 \mathrm{Ra}$ activity ratio ranges from 0.2 to 0.8 (Yamada and Nozaki 1986; Nakano-Ohta and Sato 2006; Ohta et al. 2009). The ${ }^{228} \mathrm{Ra} /{ }^{226} \mathrm{Ra}$ activity ratio in the Matsusaki sample is of the same order of magnitude as the Pacific Ocean seawater around modern Japan. ${ }^{226} \mathrm{Ra}$ and ${ }^{228} \mathrm{Ra}$ are decay products of ${ }^{238} \mathrm{U}$ and ${ }^{232} \mathrm{Th}$, respectively. Therefore, the ${ }^{232} \mathrm{Th}$ in the adhering substance might have originated in part from seaweed or seagrass. Because the adhering substance at Matsusaki contains ${ }^{232} \mathrm{Th}$, it may have originated in part from marine products.

In Japan during the Jomon period, it was known that salt could only be obtained from seawater. After the Jomon period, materials used for salt production and the process by which salt was obtained are thought to have changed. The type of salt, called moshio, was first made after the Jomon period, and moshio is thought to have been made from seaweed and seawater. Moshio was probably produced at the Matsusaki site. Mori (1991) analyzed the number and type of diatoms in a sample of precipitate adhering to a wooden tub used to store brine from the Matsusaki site. The most prevalent diatom was Cocconeis scutellum, a marine epiphytic diatom, which suggests that moshio was produced at the Matsusaki site.

If part of the material of the Hirohata sample was from seaweed or seagrass, the daughter nuclides of uranium and thorium would still be present. However, no U-series and Th-series daughter nuclides were measured in the Hirohata sample.

The concentrations of $U$ and Th in seawater are ultra-low: 2.6-3.7 $\times 10^{-6}$ (Somayajulu and Goldberg

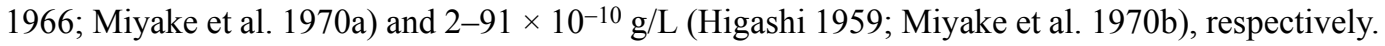
Seaweed and seagrass are able to concentrate considerable amounts of $U$ and Th from seawater (Kuwahara et al. 1997; Shiraishi et al. 2000). The high concentrations of Fe, Mn, ${ }^{238} \mathrm{U},{ }^{234} \mathrm{U}$, and ${ }^{232} \mathrm{Th}$ in the Matsusaki sample suggest that at least part of the material of the sample was seaweed or seagrass, whereas ${ }^{226} \mathrm{Ra}$ (decay product of ${ }^{238} \mathrm{U}$ ) and ${ }^{228} \mathrm{Ra}$ (decay product of ${ }^{232} \mathrm{Th}$ ) could not be detected in the material of the Hirohata sample. This finding, and the low concentrations of Fe and $\mathrm{Mn}$ in the Hirohata sample, suggest that no part of the material of the Hirohata sample could have 
derived from seaweed or seagrass. This result is not contradicted by the concentrations of the major elements in the adhering substance from Hirohata.

\section{CONCLUSION}

The analyzed white substance from the Hirohata site was contaminated by rainwater that fell after atmospheric nuclear testing and also by the earthenware to which it had adhered. Although the sampled material from both sites was calcite, the material from Matsusaki differed in some ways from that of Hirohata. The chemical elements that were more abundant in the Matsusaki sample than in the Hirohata sample, Fe, Mn, ${ }^{238} \mathrm{U}$, and ${ }^{232} \mathrm{Th}$ (parent of ${ }^{228} \mathrm{Ra}$ ), are also abundant in seaweed and seagrass, indicating that the adhering substance of the Matsusaki sample originated in part from seaweed or seagrass. This inference is supported by the discovery of diatoms in the Matsusaki sample (Mori 1991).

\section{ACKNOWLEDGMENTS}

The authors thank Ms Miyuki Miyahara and Ms Kikuko Tanaka, Research Reactor Institute, Kyoto University, for their kind support. The work was supported by a Grant-in-Aid for Young Scientists (B). Some of the funding for this study was from a Grant-in-Aid for Scientific Research (A). A part of this study is the result of the "Strategic Promotion Program for Basic Nuclear Research" carried out under the Strategic Promotion Program for Basic Nuclear Research by the Ministry of Education, Culture, Sports, Science and Technology of Japan. We thank Dr Yaroslav V Kuzmin for valuable comments on the manuscript.

\section{REFERENCES}

Higashi S. 1959. Estimation of microgram amount of thorium in sea water. Journal of Oceanographical Society of Japan 15(2):61-3.

Hughen KA, Baillie MGL, Bard E, Beck JW, Bertrand CJH, Blackwell PG, Buck CE, Burr GS, Cutler KB, Damon PE, Edwards RL, Fairbanks RG, Friedrich M, Guilderson TP, Kromer B, McCormac G, Manning S, Bronk Ramsey C, Reimer PJ, Reimer RW, Remmele S, Southon JR, Stuiver M, Talamo S, Taylor FW, van der Plicht J, Weyenmeyer CE. 2004. Marine04 marine radiocarbon age calibration, 0-26 cal kyr BP. Radiocarbon 46(3): 1059-86.

Joshi LU, Zingde MD. 1988. Uranium series disequilibrium in the coastal surface sediments and sea water of the Arabian Sea. Journal of Radioanalytical and Nuclear Chemistry 120(2):275-80.

Kuwahara C, Koyama K, Sugiyama H. 1997. Estimation of daily uranium ingestion by urban residents in Japan. Journal of Radioanalytical and Nuclear Chemistry 220(2):161-5.

Libby WF. 1946. Atmospheric helium three and radiocarbon from cosmic radiation. Physical Review 69(11-12):671-2.

Mori Y. 1991. Keisou bunseki ni yotte erareta kodai seien ni tuiteno ichikousatu [A consideration about ancient salt-making based on diatom analysis]. Kokogaku zassi 76(3):62-75. In Japanese.

Miyake Y, Sugimura Y, Mayeda M. 1970a. The uranium content and the activity ratio ${ }^{234} \mathrm{U} /{ }^{238} \mathrm{U}$ in marine or- ganisms and sea water in the western North Pacific. Journal of Oceanography 26(3):123-9.

Miyake Y, Sugimura Y, Yasujima T. 1970b. Thorium concentration and the activity ratios of ${ }^{230} \mathrm{Th} /{ }^{232} \mathrm{Th}$ and ${ }^{228} \mathrm{Th} /{ }^{232} \mathrm{Th}$ in seawater in the western North Pacific ocean. Journal of Oceanography 26(3):130-6

Nakamura T, Nishida I, Takada H, Okuno M, Minami M, Oda H. 2007. Marine reservoir effect deduced from ${ }^{14} \mathrm{C}$ dates on marine shells and terrestrial remains at archaeological sites in Japan. Nucllear Instruments and Methods in Physics Research B 259(1):453-9.

Nakano-Ohta T, Sato J. 2006. Determination of ${ }^{226}$ Ra and ${ }^{228} \mathrm{Ra}$ in seawater and hot-spring water. Radioisotopes 55(8):443-9.

Ohta T, Kubota T, Mahara Y, Sato J. 2009. Observation of ${ }^{228} \mathrm{Ra} /{ }^{226} \mathrm{Ra}$ activity ratio, and concentrations of ${ }^{226} \mathrm{Ra}$ and ${ }^{228} \mathrm{Ra}$ of surface seawaters in the Pacific side of Japan. In: Book of Abstracts, 4th Asia-Pacific Symposium on Radiochemistry 2009. p 45.

Shiraishi K, Tagami K, Muramatsu Y, Yamamoto M. 2000. Contributions of 18 food categories to intakes of ${ }^{232} \mathrm{Th}$ and ${ }^{238} \mathrm{U}$ in Japan. Health Physics 78(1):28-36.

Shishikura M, Echigo T, Kaneda H. 2007. Marine reservoir correction for the Pacific coast of central Japan using ${ }^{14} \mathrm{C}$ ages of marine mollusks uplifted during historical earthquakes. Quaternary Research 67(2): 286-91.

Somayajulu BLK, Goldberg ED. 1966. Thorium and uranium isotopes in seawater and sediments. Earth and 
Planetary Science Letters 1(3):102-6.

Uchrin G, Csaba E, Hertelendi E, Ormai P, Barnabas I. 1992. ${ }^{14} \mathrm{C}$ release from a Soviet-designed pressurized water reactor nuclear power plant. Health Physics 63(6):651-5.

Yamada M, Nozaki Y. 1986. Radium isotopes in coastal and open ocean surface water of the western North Pacific. Marine Chemistry 19(4):379-89.

Yamamoto T. 1995. Hikaku seibutu chikyuu kagaku no kosou [Conception of comparative biogeochemistry]. Transactions of the Research Institute of Oceanochemistry 8(1):21-53. In Japanese. 